\title{
RANCANG BANGUN SISTEM DAUR ULANG MINYAK GORENG BEKAS BERBASIS ALGORITMA FUZZY LOGIC
}

\author{
Andi Sri Irtawaty \\ Jurusan Teknik Elektronika \\ Politeknik Negeri Balikpapan \\ Email: andi.sri@poltekba.ac.id \\ Maria Ulfah \\ Jurusan Teknik Elektronika \\ Politeknik Negeri Balikpapan \\ Email: maria.ulfah@poltekba.ac.id
}

\begin{abstract}
ABSTRAK
System pengolahan daur ulang minyak goreng bekas menjadi minyak goreng jernih dan biodiesel dilakukan secara otomatis menggunakan Arduino Mega berbasis Algoritma Fuzzy Logic dengan menggunakan software program arduino yang mirip dengan bahasa pemograman $\mathrm{C}$ (arduino). Tujuan akhir dari penelitian ini meningkatkan income perkapita bagi pengusaha gorengan dan menghemat pengeluaran belanja bagi ibu-ibu rumah tangga, serta mengurangi limbah minyak jelantah yang dapat mencemari lingkungan. Prosentase keakuratan hasil uji coba dari penelitian ini sebesar 90\%. Untuk system daur ulang penjernihan minyak, pengendapan selama 24 jam menghasilkan penurunan kadar peroksida dan FFA sesuai standar SNI yaitu 1.25 dan 0.1119. Sedangkan untuk system daur ulang minyak jelantah menjadi biodiesel, pengendapan selama 24 jam menghasilkan biodiesel yang dapat menjadi bahan bakar untuk mesin diesel.
\end{abstract}

Kata kunci: minyak jelantah; peroksida; FFA; biodisel; arduino; algoritma fuzzy logic.

\begin{abstract}
Waste oil recycling treatment system to be recycled clear cooking oil and biodisel is done automatically using Arduino Mega-based Fuzzy Logic and using arduino software program similar to the $C$ programming language (arduino). The final purposes of this research is to increase income per capita for fried entrepreneurs and to save money on shopping for housewives, and to reduce waste of cooking oil that can pollute the environment. The percentage of accuracy of trial result from this research is $90 \%$. For oil purification recycling system, the best of precipitation is 24 hours, result peroxide and FFA are 1.25 and 0.1119. As for the system of recycling the cooking oil into biodiesel, the best precipitation is 24hours, result biodisel which can move diesel engine.
\end{abstract}

Keywords: waste oil; peroxide; FFA; biodisel; arduino; fuzzy logic algorithm.

\section{PENDAHULUAN}

\subsection{Latar Belakang}

Minyak goreng merupakan salah satu kebutuhan utama bagi industry gorengan dan ibu-ibu rumah tangga. Di Indonesia, rata-rata minyak goreng berasal dari nabati .[1], yaitu dari kelapa sawit (khusus untuk minyak goreng kemasan) dan ada juga dari kelapa biasa yang dikenal dengan istilah minyak curah. Namun minyak curah memiliki kandungan lemak dan .kandungan asam oleat yang tinggi dibandingkan minyak kemasan. [2]

Minyak goreng yang telah digunakan berkali-kali pada suhu tinggi akan menyebabkan penurunan mutu minyak goreng karena telah mengandung zat karsinogenik yang berbahaya bagi kesehatan tubuh.[3] Parameter utama yang menjadi tolok ukurnya adalah peroksida dan FFA. Oleh karena itu, minyak goreng yang telah digunakan 2 sampai 3 kali, sebaiknya dijernihkan dengan arang kayu aktif, sehingga kadar peroksida dan FFA nya akan mendekati normal, artinya aman untuk dikonsumsi kembali.

Khusus untuk minyak goreng yang telah berwarna kehitaman, sebaiknya didaur ulang menjadi biodiesel yaitu sumber energy alternative yang dapat digunakan sebagai bahan bakar mesin diesel [4]. Terkait dengan penjelasan di atas, maka latar belakang dari penelitian ini merupakan faktor yang sangat 
urgen bagi masyarakat secara luas, yaitu meningkatkan pendapatan (income) perkapita bagi pengusaha gorengan dan penghematan belanja dapur bagi ibu-ibu rumah tangga dalam penggunaan minyak goreng untuk keperluan sehari-hari serta mengurangi limbah minyak jelantah dari industry gorengan dan masyarakat pengguna minyak goreng, yaitu dengan mendaur ulang minyak jelantah tersebut menjadi biodiesel.

\subsection{Rumusan Masalah}

Terkait dengan latar belakang yang telah diuraikan, maka rumusan masalah pada penelitian ini adalah sebagai berikut :

1) Bagaimana merancang system penjernih minyak goreng bekas berbasis Arduino mega dengan bahan dasar penjernih berupa arang kayu aktif?

2) Bagaimana merancang sistem daur ulang minyak jelantah berbasis Arduino mega dengan bahan daur ulang berupa methanol dan $\mathrm{NaOH}$ menjadi biodiesel ?

\subsection{Tujuan khusus}

Tujuan khusus penelitian ini sebagai berikut:

1) Menjernihkan minyak goreng bekas dengan bahan penjernih dari arang kayu, sehingga masih layak dikonsumsi.

2) Mendaur ulang minyak jelantah dengan bahan dasar methanol dan $\mathrm{NaOH}$ menjadi biodiesel (sumber energy alternatif).

\subsection{Tinjauan Pustaka}

Minyak goreng yang paling umum digunakan di Indonesia, adalah minyak yang berasal dari nabati [1]. Minyak goreng merupakan salah satu kebutuhan pokok bagi industry gorengan dan ibu-ibu rumah tangga. Hampir semua kalangan menyukai gorengan. Namun perlu diperhatikan, bahwa minyak goreng yang telah digunakan lebih dari 3 kali, dapat membahayakan kesehatan tubuh, karena meningkatnya kadar peroksida dan FFA akibat penggunaan pada suhu tinggi, dapat menyebabkan timbulnya penyakit berbahaya, seperti kolesterol, jantung coroner bahkan dapat memicu penyakit kanker. Dalam memilih minyak goreng, ada beberapa parameter penting yang perlu diperhatikan, diantaranya tahan terhadap tekanan oksidatif, memiliki titik asap yang tinggi dan kandungan asapnya rendah setelah digunakan untuk menggoreng [2]. Minyak goreng yang telah digunakan berulang kali dinamakan minyak jelantah dan warnanya coklat kehitaman. Minyak jelantah mengandung senyawa peroksida dan FFA (Free Fatty Acid) yang tinggi. Menurut pakar kesehatan, jika kadar peroksida dan FFA pada minyak goreng sudah melampaui batas ambang normal yang disarankan, maka minyak goreng tersebut akan bersifat karsinogenik dan dapat memicu berbagai penyakit berbahaya, seperti jantung koroner dan kanker.

Pada penelitian ini, telah dirancang teknologi baru berupa alat otomatis berbasis arduino mega yang dapat mendaur ulang minyak goreng bekas / minyak jelantah menjadi produk akhir berupa minyak goreng jernih yang layak dikonsumsi kembali oleh manusia dengan kadar peroksida dan FFA yang lebih rendah dari kondisi sebelumnya (sesuai standar SNI 7709 : 2012, butir A5 dan A4), dan biodiesel (sumber energy alternative yang dapat digunakan sebagai bahan bakar untuk menyalakan kompor sumbu tradisional, membakar kertas, kayu, bahkan dapat digunakan untuk pengganti bahan bakar mesin diesel yang ramah lingkungan). Metode fuzzy logic sangat tepat diterapkan dalam analisa prinsip kerja alat tersebut dengan ketentuan sebagai berikut :

Jika warna minyak goreng bekas : keruh, kuning kecoklatan, maka alat yang bekerja adalah system daur ulang penjernihan minyak goreng. Sebaliknya jika warna minyak goreng bekas : keruh, coklat kehitaman, maka alat yang bekerja adalah system daur ulang pembuatan biodiesel.

System daur ulang minyak goreng bekas akan dilakukan sesuai tingkat gradasi warna minyak goreng. Jika warnanya kuning kecoklatan, maka dapat dijernihkan dengan mencampurnya dengan arang kayu yang telah dihaluskan. Untuk $500 \mathrm{ml}$ minyak goreng bekas, dibutuhkan arang kayu 2 potong dan dihaluskan. Setelah diaduk selama 15 menit, proses selanjutnya didiamkan selama 24 jam dan hasilnya disaring dengan kertas lab, lalu dapat digunakan kembali untuk menggoreng. Namun jika warnanya coklat kehitaman, maka akan didaur ulang menjadi biodiesel, dengan cara mencampur minyak jelantah dengan methanol dan $\mathrm{NaOH}$, diaduk selama 5 menit. Apabila $\mathrm{NaOH}$ berupa Kristal, maka dilarutkan terlebih dahulu dengan methanol dengan perbandingan $100 \mathrm{ml}$ methanol dan setengah sendok makan $\mathrm{NaOH}$, untuk mendaur ulang minyak jelantah $500 \mathrm{ml}$.

Perancangan Alat Sistem Daur Ulang Minyak Goreng Bekas / Minyak Jelantah terdiri atas Arduino Mega, LCD, sensor warna, motor dc, solenoid valve dan sensor ultrasonic. 
1) Arduino Mega 2560

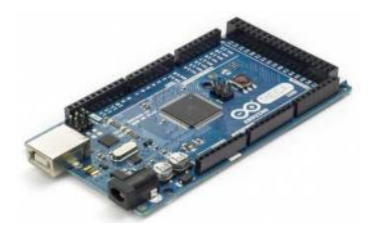

Gambar 1. Tampilan Fisik Arduino Mega

Sumber : https://store.arduino.cc/usa/arduino-mega-2560-rev3

Arduino Mega 2560 seperti yang ditunjukkan pada gambar 1 berfungsi sebagai pengontrol kerja seluruh system penjernih minyak goreng bekas dan system daur ulang minyak jelantah menjadi biodisel, terdiri atas 54 pin.

2) LCD

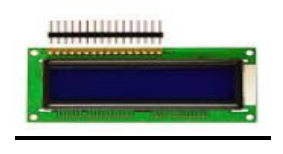

Gambar 2. Tampilan Fisik LCD

Sumber : https://www.arduino.cc/en/Tutorial/LiquidCrystalDispla

LCD (Liquid Crystal Display) seperti yang ditunjukkan pada gambar 2 berfungsi menampilkan proses tahapan dari system (status kerja alat) dengan jumlah karakter 2 x 16. Jumlah pin pada LCD adalah 16.

3) Sensor Warna TCS3200

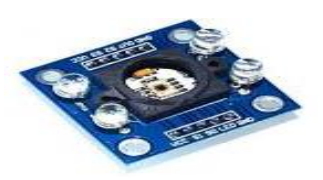

\section{Gambar 3. Tampilan Fisik Sensor Warna}

Sumber : www.keyence.co.id

Sensor Warna TCS3200) seperti yang ditunjukkan pada gambar 3 akan digunakan untuk mendeteksi warna minyak goreng bekas. Jika warna minyak goreng terdeteksi masih berwarna cerah (coklat kekuningan), maka alat yang bekerja adalah system penjernih minyak goreng bekas. Sedangkan jika warna minyak goreng telah coklat kehitaman, maka alat yang bekerja adalah system daur ulang minyak jelantah menjadi biodiesel.

4) Sensor Ultrasonik HC-SR04

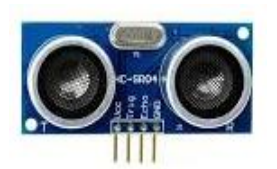

Gambar 4. Tampilan Fisik Sensor Ultrasonic

Sumber : https://www.microkitselectronica.com/media/.

Sensor ultrasonic ) seperti yang ditunjukkan pada gambar 4 berfungsi mendeteksi ketinggian level minyak goreng pada wadah penampungan untuk dijernihkan atau diudaur ulang menjadi biodiesel. Penyettingan level ketinggian minyak goreng pada wadah, disetting di Arduino mega 2560. 
5) Motor DC $300 \mathrm{rpm}$

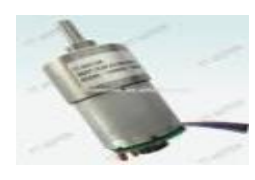

Gambar 5. Tampilan Fisik Motor DC

Sumber : www.e-jpc.com/pdf/dcmotors601-0241.pdf

Motor DC ) seperti yang ditunjukkan pada gambar 5 berfungsi menggerakkan pengaduk pada system penjernih minyak goreng bekas, dan pengaduk pada system daur ulang minyak jelantah menjadi biodiesel (wadah pencampuran minyak jelantah dengan methanol dan $\mathrm{NaOH}$ ). Pada motor DC, sumbernya adalah arus searah atau yang juga biasa dikenal dengan nama listrik DC. Motor DC dapat berputar searah maupun berlawanan arah jarum jam. Untuk membalikan arah putaran, cukup dengan membalikan polaritas listriknya. Pada umumnya sebuah motor DC memerlukan tegangan antara 1,5 volt sampai dengan 24 volt. Sedangkan untuk polaritasnya dari 3.000 RPM sampai dengan 8.000 RPM tergantung spesifikasi dan tegangan yang diberikan. Semakin besar tegangan yang diberikan, maka semakin tinggi RPM nya. Dan semakin kecil tegangan yang diberikan, maka semakin rendah pula RMP nya.

6) Pompa

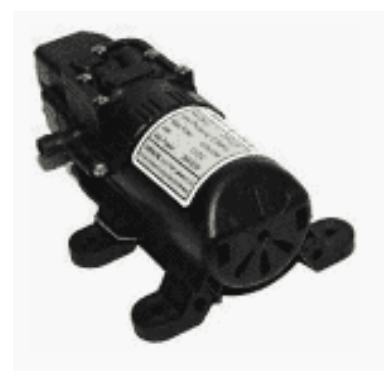

Gambar 6. Tampilan Fisik Pompa Air

Sumber : https://www.google.com/search?safe=strict\&source=hp\&ei=YwlW6SNLcr0vASU6YGwDg\&btnG=Search\&q=pompa+air

Pompa seperti yang ditunjukkan pada gambar 6 berfungsi untuk memberikan tekanan pada fluida, sehingga minyak goreng yang diproses dari satu tahapan ke tahapan berikutnya dapat mengalir dengan deras.

\section{METODOLOGI PENELITIAN}

Penelitian ini dilaksanakan selama empat bulan berturut-turut, dan adapun tempat penelitian dan tahapan penenelitian akan diuraikan sebagai berikut :

\subsection{Tempat Penelitian}

Kegiatan penelitian berpusat di Laboratorium Elektronika Politeknik Negeri Balikpapan, dan di Laboratorium Balai Riset dan Standarisasi Industri Samarinda (Baristand Industri Samarinda).

\subsection{Tahapan penelitian}

Berdasarkan jadwal penelitian yang telah ditentukan, maka tahapan penelitian terdiri atas 5 tahapan, yang akan diuraikan sebagai berikut :

\subsubsection{Tahapan I (Persiapan)}

Pada tahap ini, persiapan yang dilakukan diawali dengan studi literature dari permasalahan yang dikemukakan. Selain itu persiapan alat dan bahan. Peralatan utama berupa Arduino Mega 2560, LCD, sensor warna TCS3200, sensor ultrasonic dan pompa air. Sedangkan bahan dasar penjernih minyak 
goreng bekas adalah arang kayu aktif, dan bahan daur ulang minyak jelantah menjadi biodiesel berupa methanol dan $\mathrm{NaOH}$.

\subsubsection{Tahapan II (Perancangan Alat)}

Perancangan system ini terdiri atas 2 bagian yaitu perancangan system penjernih minyak goreng bekas dan perancangan system daur ulang minyak goreng jelantah menjadi biodiesel. Adapun diagram alir (flowchart) dari kedua system tersebut disajikan pada gambar 7 .

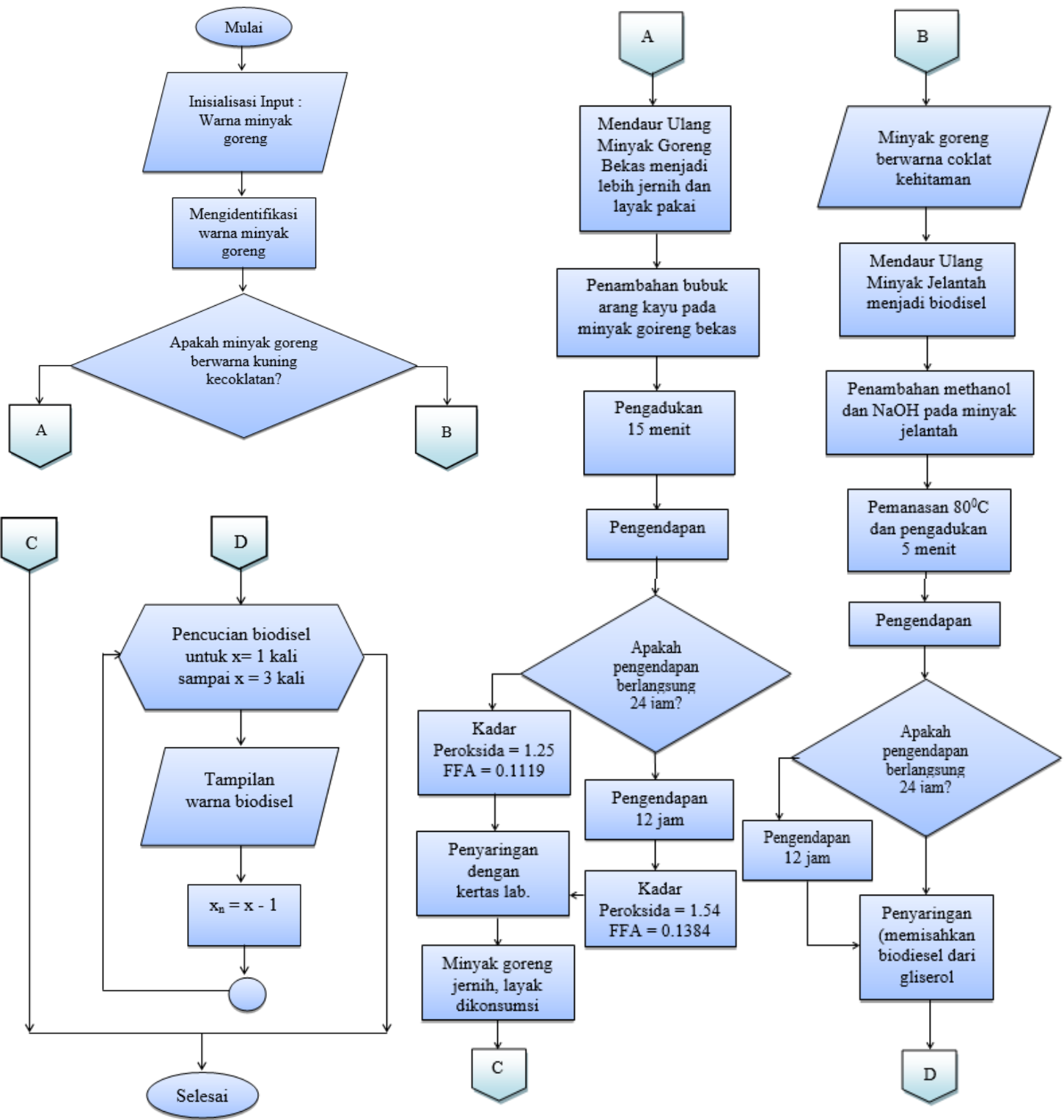

Gambar 7. Diagram Alir / Flowchart Sistem Daur Ulang

\subsubsection{Tahapan III (Pengujian Alat)}

Tahap ini adalah tahap pengujian, dimana alat yang dirancang tersebut akan diuji sesuai spesifikasi yang diinginkan. Penerapan metode Fuzzy Logic dilakukan untuk menentukan perlakuan system daur ulang terhadap minyak goreng bekas / minyak jelantah berdasarkan tampilan warna minyak. Ada 2 produk akhir yang akan diuji kualitasnya. Pengujian pertama yaitu mengukur parameter keluaran system daur ulang penjernih minyak goreng bekas, dengan parameter uji peroksida dan FFA. Pengujian sampel penjernihan minyak goreng dilakukan di laboratorium Balai Riset dan Standarisasi Industri Samarinda (membandingkan kadar peroksida dan FFA untuk pengendapan 12 jam dan 24 jam). Pengujian kedua 
yaitu menguji kemampuan biodiesel sebagai pengganti bahan bakar (membandingkan biodiesel untuk pengendapan 12 jam dan 24 jam).

\subsubsection{Tahapan IV (Analisa dan Pembahasan)}

Berdasarkan hasil pengujian, ternyata biodiesel dengan masa pengendapan 12 jam dapat membakar kertas, tisu, plastik, daun, dan kayu Sedangkan biodiesel dengan masa pengendapan 24 jam, dapat membakar kertas, tisu, plastik, daun, kayu dan ubin. Bahkan jika proses pencucian biodiesel sampai 3 kali, dapat menjadi bahan bakar pengganti solar.

\subsubsection{Tahapan V(Kesimpulan)}

Pada tahapan ini, ada 2 kesimpulan akhir yaitu kesimpulan pertama system penjernihan minyak goreng bekas, hasilnya jauh lebih baik untuk pengendapan selama 24 jam, dimana kadar peroksida dan FFA minyak goreng hasil daur ulang mendekati normal sesuai standar SNI. Kesimpulan kedua yaitu system daur ulang minyak jelantah menjadi biodiesel, hasilnya jauh lebih baik saat pengendapan 24 jam dengan proses pencucian 2 sampai 3 kali (lebih jernih).

\subsection{Road Map Penelitian}

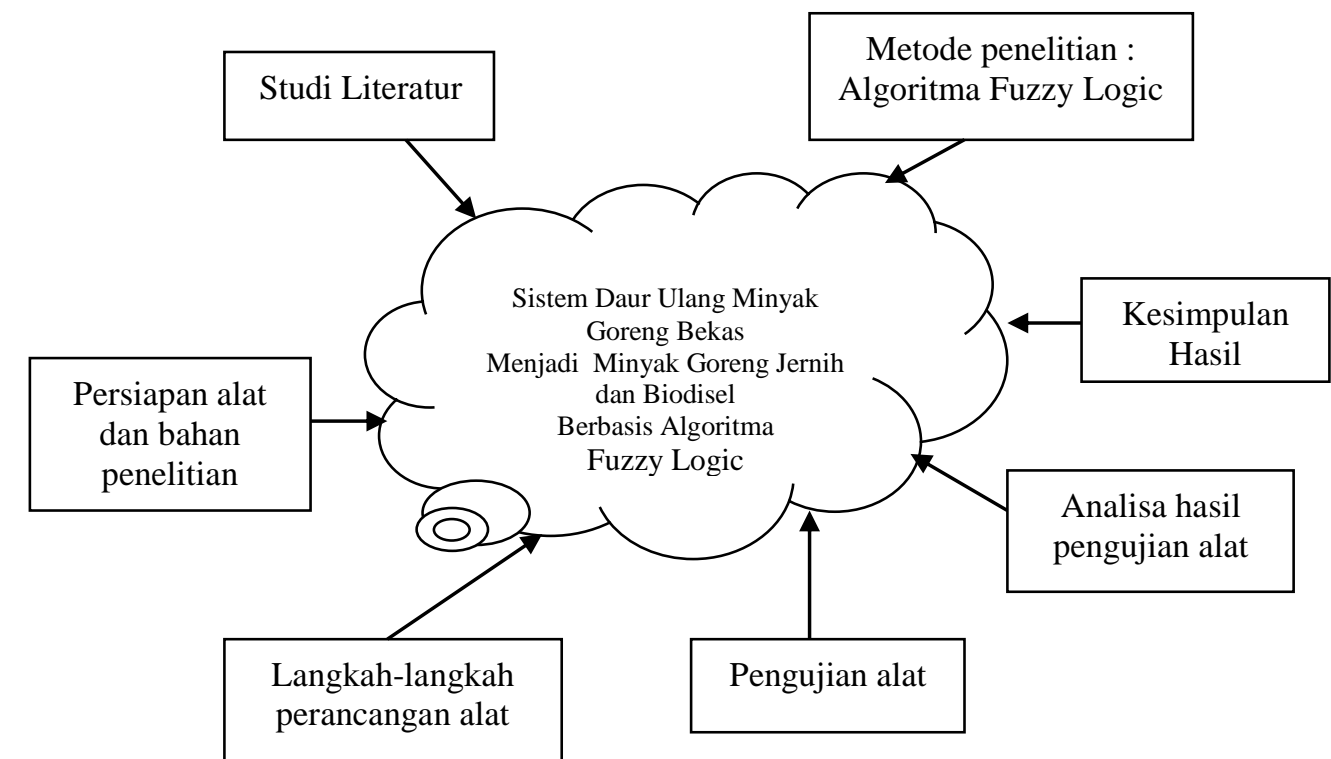

Gambar 8. Road Map Penelitian

\section{HASIL DAN PEMBAHASAN}

Hasil perancangan alat sistem daur ulang minyak goreng bekas / minyak jelantah, seperti yang disajikan pada gambar 9 berikut :

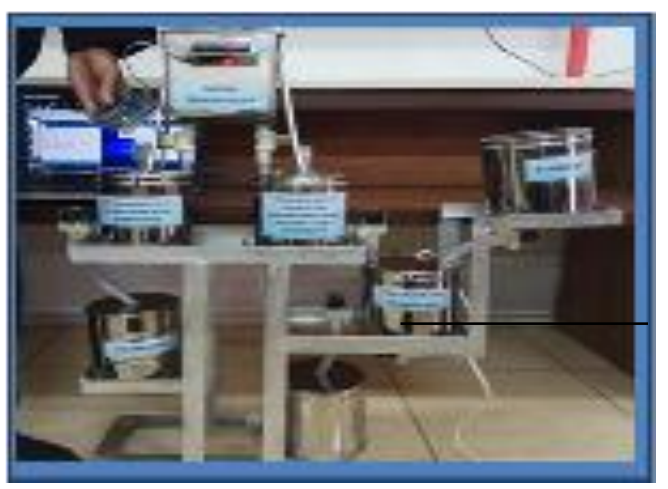

Gambar 9. Alat Sistem Daur Ulang Minyak Goreng Bekas / Minyak Jelantah 
Berdasarkan implementasi metode "Fuzzy Logic", prinsip kerja alat menggunakan sensor pendeteksi warna minyak goreng bekas. Jika warna minyak goreng keruh kuning kecoklatan, maka katub solenoid 1 (proses penjernihan minyak goreng bekas) yang akan bekerja. Jika warna minyak goreng keruh coklat kehitaman, maka katub solenoid 2 (proses pembuatan biodiesel) yang akan bekerja.

\subsection{Sistem Daur Ulang Minyak Goreng Bekas Menjadi Minyak Goreng Jernih}

Berdasarkan syarat mutu minyak goreng menurut SNI 01-3741-2002 [6], disajikan pada tabel 1.

Tabel 1. Syarat mutu minyak goreng menurut SNI 01-3741-2002

\begin{tabular}{ccc}
\hline Kriteria Uji & Satuan & Mutu \\
\hline & Keadaan & Normal \\
Bau & - & Normal \\
Rasa & - & Putih kuning pucat sampai kuning \\
Warna & - & $0.01-0.30$ \\
Kadar Air & $\% \mathrm{~b} / \mathrm{b}$ & \\
& Asam lemak bebas & Maks 0.30 \\
Asam laurat & $\% \mathrm{~b} / \mathrm{b}$ & Maks 2.00 \\
Asam linoleate & $\% \mathrm{~b} / \mathrm{b}$ & Maks 0.30 \\
Asam palmitate & $\% \mathrm{~b} / \mathrm{b}$ & Maks 0.30 \\
Asam oleat & $\% \mathrm{~b} / \mathrm{b}$ & Maks 0.60 \\
Bilangan asam & $\mathrm{mg} \mathrm{KOH} / \mathrm{g}$ & Maks 1.00 \\
Bilangan peroksida & $\mathrm{mg} \mathrm{O} / 100 \mathrm{~g}$ &
\end{tabular}

Uji coba kelayakan minyak goreng bekas berdasarkan parameter kadar peroksida dan FFA dapat dikelompokkan dengan menggunakan aplikasi program matlab berbasis fuzzy logic, seperti yang ditampilkan pada gambar 10 dan gambar 11 .

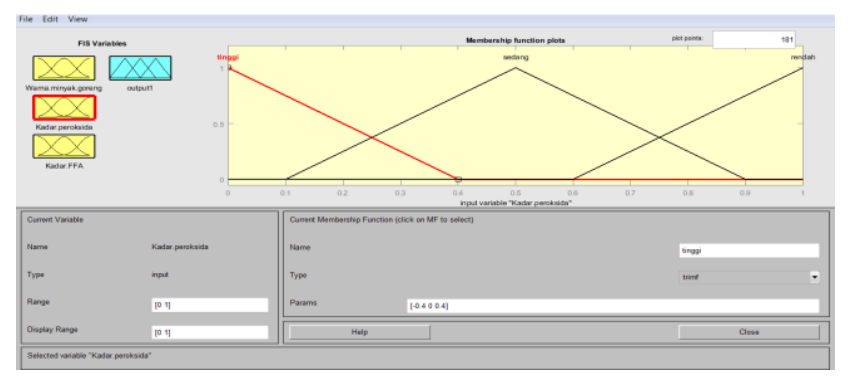

Gambar 10. Tampilan Variable Input

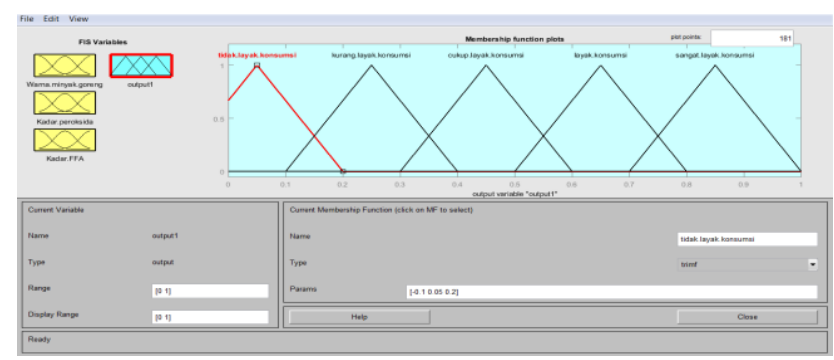

Gambar 11. Tampilan Variable Output

Berdasarkan aturan rules pada pemrograman matlab berbasis fuzzy logic, maka range kadar peroksida dan FFA pada minyak goreng bekas disajikan pada tabel 2 berikut: 
Tabel 2. Status kelayakan dari kadar peroksida dan ffa berdasarkan aturan rules program fuzzy logic untuk beberapa kondisi sampel minyak goreng

\begin{tabular}{ccccc}
\hline No & $\begin{array}{c}\text { Warna minyak goreng } \\
\text { bekas }\end{array}$ & Kadar Peroksida & Kadar FFA & Keterangan \\
\hline 1 & Keruh Kecoklatan & 2.71 & 0.4211 & Tidak layak \\
2 & Keruh Kecoklatan & 2.51 & 0.4001 & Tidak layak \\
3 & Keruh Kecoklatan & 2.21 & 0.3211 & Kurang layak \\
4 & Keruh Kecoklatan & 2.01 & 0.3001 & Kurang layak \\
5 & Keruh Kecoklatan & 1.86 & 0.2333 & Cukup Layak \\
6 & Keruh Kekuningan & 1.75 & 0.2111 & Cukup Layak \\
7 & Keruh Kekuningan & 1.60 & 0.1514 & Layak \\
8 & Keruh Kekuningan & 1.54 & 0.1384 & Layak \\
9 & Jernih & 1.25 & 0.1119 & Sangat Layak \\
\hline
\end{tabular}

Untuk mendukung tabel 2, maka kadar peroksida dan FFA yang diperoleh dari hasil uji laboratorium Balai Riset dan Standarisasi Industri Samarinda (gambar 12) pada sampel hasil penjernihan minyak goreng bekas disajikan pada tabel 3 .

Tabel 3. Kadar peroksida dan FFA (asam lemak bebas) pada minyak goreng hasil daur ulang

\begin{tabular}{|c|c|c|c|c|c|}
\hline No & $\begin{array}{c}\text { Lamanya } \\
\text { Pengendapan }\end{array}$ & Parameter & Satuan & Hasil Uji & Metode Uji \\
\hline \multirow{2}{*}{1} & \multirow{2}{*}{0 jam } & $\begin{array}{c}\text { Bilangan } \\
\text { Peroksida }\end{array}$ & Mek $\mathrm{O}_{2} / \mathrm{kg}$ & 1.60 & SNI 7709:2012, Butir A.5 \\
\hline & & $\begin{array}{c}\text { Asam Lemak } \\
\text { Bebas }\end{array}$ & $\%$ & 0.1514 & SNI 7709:2012, Butir A.4 \\
\hline \multirow{2}{*}{2} & \multirow{2}{*}{12 jam } & $\begin{array}{l}\text { Bilangan } \\
\text { Peroksida }\end{array}$ & Mek $\mathrm{O}_{2} / \mathrm{kg}$ & 1.54 & SNI 7709:2012, Butir A.5 \\
\hline & & $\begin{array}{c}\text { Asam Lemak } \\
\text { Bebas }\end{array}$ & $\%$ & 0.1384 & SNI 7709:2012, Butir A.4 \\
\hline \multirow{2}{*}{3} & \multirow{2}{*}{24 jam } & $\begin{array}{l}\text { Bilangan } \\
\text { Peroksida }\end{array}$ & Mek $\mathrm{O}_{2} / \mathrm{kg}$ & 1.25 & SNI 7709:2012, Butir A.5 \\
\hline & & $\begin{array}{c}\text { Asam Lemak } \\
\text { Bebas }\end{array}$ & $\%$ & 0.1119 & SNI 7709:2012, Butir A.4 \\
\hline
\end{tabular}

Berdasarkan hasil uji laboratorium kadar peroksida dan FFA sampel minyak goreng yang telah didaur ulang, maka dapat disimpulkan bahwa proses pengendapan selama 24 jam berhasil menurunkan kadar peroksida dan FFA mendekati kondisi yang sangat ideal (sesuai standar SNI 01-3741-2002 pada tabel 1). Artinya minyak goreng tersebut telah terstandar SNI dan layak dikonsumsi kembali.

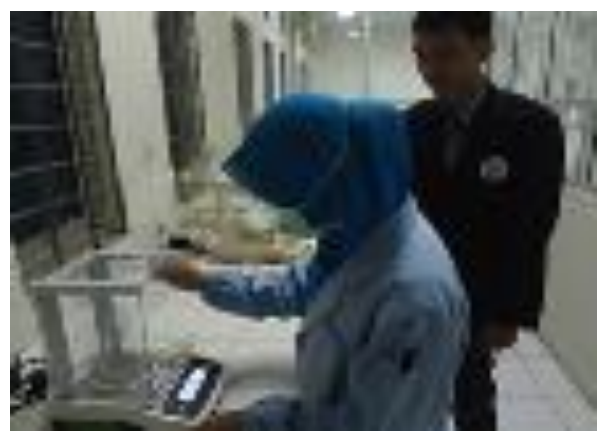

Gambar 12. Proses Uji Laboratorium Sampel Minyak Goreng Hasil Daur Ulang

\subsection{Sistem Daur Ulang Minyak Jelantah Menjadi Biodisel}

Berdasarkan hasil uji coba alat system daur ulang minyak jelantah menjadi biodiesel, maka hasilnya tersaji pada tabel 4 berikut : 
Tabel 4. Hasil uji coba kemampuan biodiesel yang terbentuk dari hasil daur ulang minyak jelantah

\begin{tabular}{|c|c|c|c|c|c|c|c|c|c|c|}
\hline \multirow[b]{2}{*}{ No } & \multirow[b]{2}{*}{$\begin{array}{c}\text { Masa } \\
\text { Pengendapan }\end{array}$} & \multirow{2}{*}{$\begin{array}{c}\text { Warna } \\
\text { biodiesel } \\
\text { yang } \\
\text { terbentuk }\end{array}$} & \multicolumn{8}{|c|}{ Kemampuan membakar material } \\
\hline & & & Tisu & Kertas & Plastik & Daun & Кауи & $\begin{array}{c}\text { Kaleng } \\
\text { Aluminium }\end{array}$ & Ublik & $\begin{array}{r}\text { Mesin } \\
\text { diesel }\end{array}$ \\
\hline 1 & 0 jam & & $\sqrt{ }$ & $\sqrt{ }$ & - & & - & - & - & - \\
\hline 2 & 12 jam & & $\sqrt{ }$ & $\sqrt{ }$ & $\sqrt{ }$ & $\sqrt{ }$ & $\sqrt{ }$ & $\sqrt{ }$ & $\sqrt{ }$ & - \\
\hline 3 & 24 jam & 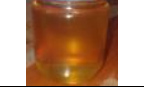 & $\sqrt{ }$ & $\sqrt{ }$ & $\sqrt{ }$ & $\sqrt{ }$ & $\sqrt{ }$ & $\sqrt{ }$ & $\sqrt{ }$ & $\sqrt{ }$ \\
\hline
\end{tabular}

Pada tabel 4 terlihat bahwa pengendapan campuran minyak jelantah, methanol dan $\mathrm{NaOH}$ pada 0 jam, hanya menghasilkan biodiesel yang dapat membakar kertas dan tisu; pada pengendapan 12 jam, biodiesel mampu membakar kertas, tisu, plastic, daun, kayu, kaleng aluminium dan ublik; sedangkan pada pengendapan 24 jam dapat membakar semua material bahkan dapat digunakan sebagai bahan bakar pengganti mesin diesel (contohnya mesin pompa air untuk perkebunan Samboja, seperti yang diperlihatkan pada gambar 13).

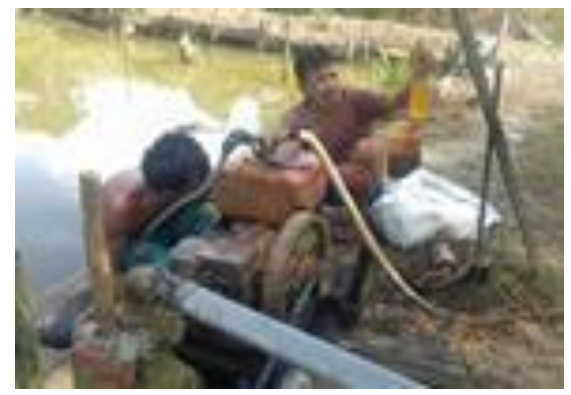

\section{Gambar 13. Uji Coba Biodiesel Pada Mesin Pompa Air Di Area Perkebunan Samboja}

Dengan menggunakan software program matlab berbasis metode fuzzy logic, maka keakuratan hasil uji coba kemampuan biodiesel dalam membakar material pada tabel 4 akan audibuktikan secara nyata melalui simulasi program matlab berbasis metode algoritma fuzzy logic, seperti yang tersaji pada gambar 14 dan gambar 15.

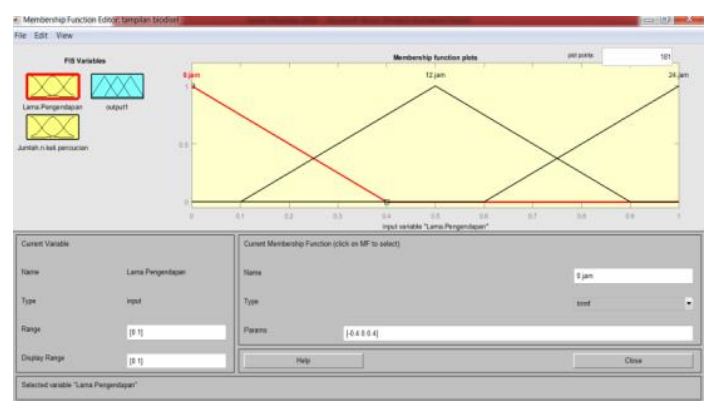

Gambar 14. Tampilan Variable Input

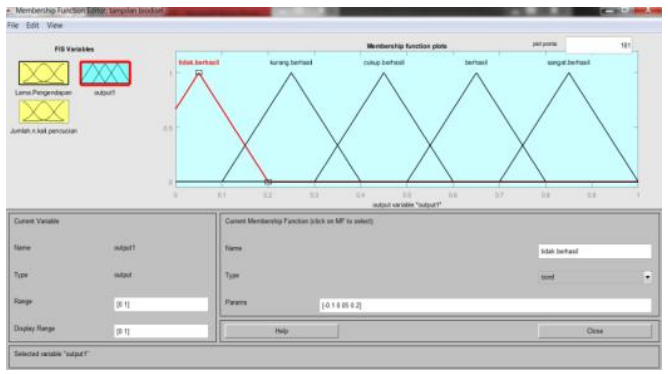

Gambar 15. Tampilan Variable Output 
Untuk mendukung hasil uji coba biodiesel pada tabel 4, maka dengan aturan rules program matlab berbasis fuzzy logic, kemampuan biodiesel hasil daur ulang dari minyak jelantah disajikan pada tabel 5 berikut :

Tabel 5. Status keberhasilan biodisel berdasarkan aturan rules program fuzzy logic untuk beberapa kondisi biodisel

\begin{tabular}{ccccc}
\hline No & Warna Biodisel & $\begin{array}{c}\text { Lama } \\
\text { Pengendapan }\end{array}$ & $\begin{array}{c}\text { Jumlah } \boldsymbol{n} \text { kali } \\
\text { Pencucian }\end{array}$ & Keterangan \\
\hline 1 & Keruh coklat kehitaman & 0 jam & $1 \mathrm{kali}$ & Tidak berhasil \\
2 & Keruh kecoklatan & 0 jam & $2 \mathrm{kali}$ & Kurang berhasil \\
3 & Keruh kecoklatan & 0 jam & $3 \mathrm{kali}$ & Kurang berhasil \\
4 & Jernih kekuningan & $12 \mathrm{jam}$ & $1 \mathrm{kali}$ & Cukup berhasil \\
5 & Jernih kekuningan & $12 \mathrm{jam}$ & $2 \mathrm{kali}$ & Cukup berhasil \\
6 & Jernih kekuningan & $12 \mathrm{jam}$ & $3 \mathrm{kali}$ & Berhasil \\
7 & Jernih kuning orange & $24 \mathrm{jam}$ & $1 \mathrm{kali}$ & Berhasil \\
8 & Jernih kuning orange & 24 jam & $2 \mathrm{kali}$ & Sangat berhasil \\
9 & Jernih kuning orange & 24 jam & $3 \mathrm{kali}$ & Sangat berhasil \\
\hline
\end{tabular}

Pada tabel 5, terlihat bahwa biodiesel yang diperoleh dari hasil daur ulang minyak jelantah dengan lama pengendapan 24 jam dan proses pencucian 2 sampai 3 kali, terbukti memiliki kemampuan dapat membakar semua jenis material, bahkan dapat berfungsi sebagai bahan bakar mesin diesel.

\section{KESIMPULAN}

Berdasarkan analisa dan pembahasan, maka dapat ditarik kesimpulan sebagai berikut : Kadar peroksida dan FFA pada minyak goreng hasil penjernihan untuk masa pengendapan 24 jam jauh lebih ideal sesuai standar SNI 01-3741-2002, daripada masa pengendapan 12 jam. Biodisel yang diperoleh dari hasil daur ulang minyak jelantah dengan masa pengendapan 24 jam dengan proses pencucian 2 sampai 3 kali, memiliki kemampuan yang hampir sama dengan solar (pengganti bahan bakar mesin diesel). Prosentase keakuratan hasil uji coba dari penelitian ini sebesar 90\%. Untuk system daur ulang penjernihan minyak, pengendapan 0 jam, kadar peroksida dan FFA masing-masing sebesar 1.60 dan 0.1514; pengendapan 12 jam, 1.54 dan 0.1384; pengendapan 24 jam 1.25 dan 0.1119. Sedangkan untuk system daur ulang minyak jelantah menjadi biodiesel, pengendapan 0 jam hanya dapat membakar kertas dan tisu, pengendapan 12 jam dapat membakar kertas, tisu, plastic, daun, kayu, kaleng aluminium dan ublik, pengendapan 24 jam dapat membakar semua material bahkan dapat menggantikan bahan bakar mesin diesel.

\section{UCAPAN TERIMA KASIH}

Kami menghaturkan terima kasih kepada seluruh pihak terkait, terutama P3M Politeknik Negeri Balikpapan, Laboratorium Jurusan Teknik Elektronika Politeknik Negeri Balikpapan dan Laboratorium Balai Riset dan Standarisasi Industri Samarinda, sehingga artikel ilmiah ini dapat terselesaikan dengan sebaik-baiknya berdasarkan hasil uji coba alat system daur ulang minyak goreng bekas berbasis metode Fuzzy Logic.

\section{DAFTAR PUSTAKA}

[1] Hariskal. 2009. "Kerusakan Minyak Goreng". [Online]. Available: http://hariskal.wordpress.com/ 2009/05/09/kerusakan-minyak-goreng/.

[2] Citra. 2007. "Jenis-jenis minyak". [Online]. Available: http://citra.wordpress.com/2009/05/09/ kerusakan-minyak-goreng/.

[3] Perkins. 1967. "Formation of Volatile Decomposition on Production in Heated Fats and Oils". J. Food Techno,. Vol. 21 (4): 125-130.

[4] H, Wijayanti. 2012. "Pemanfaatan Arang Aktif Dari Serbuk Gergaji Kayu Ulin Untuk Meningkatkan Kualitas Minyak Goreng Bekas". Retrieved from https://media.neliti.com/media/publications/107662-ID-pemanfaatan-arang-aktif-dari- $\quad$ serbukgerg.pdf. 